\title{
New Indicators Proposed to Assess Tuberculosis Control and Elimination in Cuba
}

\author{
Edilberto R. González MD PhD, Luisa Armas MD MS
}

\begin{abstract}
Following 48 years of successful operation of the National Tuberculosis Control Program, Cuban health authorities have placed tuberculosis elimination on the agenda. To this end some tuberculosis control processes and their indicators need redesigned and new ones introduced, related to: number and proportion of suspected tuberculosis cases among vulnerable population groups; tuberculosis suspects with sputum microscopy and culture results useful for diagnosis (interpretable); and number of identified contacts of reported tuberculosis cases who were fully investigated. Such new indicators have been validated and successfully implemented in all provinces (2011-12) and are in the approval pipeline for generalized use in the National Tuberculosis Control Program. These indicators complement existing criteria for quality of case detection and support more comprehensive program performance assessment.
\end{abstract}

KEYWORDS Tuberculosis, detection, monitoring, surveillance, contact tracing, disease outbreaks, program evaluation, quality indicators, Cuba

\section{INTRODUCTION}

It might seem presumptuous to speak of new indicators in tuberculosis (TB) case detection surveillance in addition to those established globally.[1,2] The rationale is grounded in the foundations of Cuba's National TB Control Program (PNCT, the Spanish acronym), established at the first meeting of tuberculosis hospitals and dispensaries in 1961 and in the first National Forum on Public Health and Epidemiology in 1962, leading to drafting the Program's guiding document in 1963, the year PNCT implementation began.[3]

In 1965, the case notification rate for TB (all forms) was 65 per 100,000 population; it steadily declined to 4.7 per 100,000 in 1991, rose to 14.5 per 100,000 in 1994[3-7] and again declined steadily to under 10 per 100,000 in 2006-2010, accompanied by a decline in mortality rates.[6-8] However, when new case notification and mortality rates reached 7 and 0.2 per 100,000 population, respectively,[3,4] some of PNCT's usual indicators became inadequate for monitoring and evaluation of program processes and impacts.

This was the situation in Cuba in 2009 when, after PNCT had successfully and continuously operated for 48 years,[5] we set out to eliminate TB. This effort has the advantages of political will; a strong national health system with an extensive and comprehensive network of free services; a strong PNCT with a national microbiological diagnostic network; a Directly Observed Treatment-Short Course (DOTS) strategy since 1971; low incidence rates for new cases and relapses; very low frequency of multidrug resistance and extreme multidrug resistance; as well as intensive control of TB/HIV co-infection-all within a framework of social and community participation.[3-8]
To eliminate TB we must improve quality of case detection, which comprises at least six dimensions, corresponding to the essential global TB control strategies:

- Selection of persons at high risk for TB (vulnerable groups)

- Achieving complete diagnosis

- Public awareness of TB, its diagnosis and curability

- Quality of preventive services

- Overall quality of diagnostic services

- Quality of outbreak control

Nine subprocesses stem from these dimensions, displayed in Table 1. The Regional Plan for Tuberculosis Control for the Americas[9] calls for reinforced quality assurance for TB control, as posed in eight specific objectives:

1. Ensure every TB patient access to health care services that include quality implementation of the DOTS strategy.

2. Decrease incidence of TB and HIV in populations affected by both infections.

3. Prevent and control multidrug-resistant TB (MDR-TB) within the framework of the DOTS strategy.

4. Guarantee timely, quality diagnosis and bacteriological monitoring through strengthened laboratory networks.

5. Involve all health care providers (public, nongovernmental and private) in TB control.

6. Reduce stigma and discrimination toward TB patients and improve access to DOTS services, with support from advocacy, communication, and social mobilization strategies and participation of affected persons.

7. Strengthen management of national tuberculosis programs through human resource development strategies that constitute an integral part of national tuberculosis program plans.

8. Develop and/or strengthen national tuberculosis programs' research capacity.

Operational indicators associated with case detection in Cuba's PNCT manual[10] were reviewed for possible improvements (Table 2).

For example, Indicator 1 from that table is used to construct a case detection coverage rate, but it does not yield insight into qualitative progress in the search for TB cases. Nor does it refer to selective prioritized case-finding for groups at high risk or vulnerable to TB, including contacts of TB patients, prisoners and ex-prisoners, HIVpositive individuals, the elderly, economically vulnerable or malnourished persons, and long-term residents of institutions. To these could be added persons with chronic diseases (diabetes, chronic obstructive pulmonary disease, renal insufficiency and malignancies, inter alia), those who are immunodepressed from prolonged treatment with immunosuppressants, and health workers who are frequently exposed. Contacts of TB patients, prisoners and exprisoners, and HIV-positive individuals are the highest priorities for PNCT.[10] Table 2 also contains some critical observations about other indicators. 


\begin{tabular}{|c|c|c|c|}
\hline Dimension addressed & Subprocess & Indicator & Calculation \\
\hline \multirow{2}{*}{$\begin{array}{l}\text { Selection of persons at } \\
\text { high risk for TB } \\
\text { (vulnerable groups) }\end{array}$} & Identification of TB suspects ${ }^{a}$ & $\begin{array}{l}\text { Proportion of TB suspects identified } \\
\text { among persons seeking health care }\end{array}$ & $\begin{array}{l}\text { TB suspects / primary care and internal } \\
\text { medicine consults }\end{array}$ \\
\hline & $\begin{array}{l}\text { TB suspects investigated who } \\
\text { belong to at least one vulnerable } \\
\text { group for } T B\left(V G^{b}\right)\end{array}$ & $\begin{array}{l}\text { Proportion of TB suspects belonging to } \\
\text { vulnerable groups }\end{array}$ & $\begin{array}{l}\text { VG TB suspects / total TB suspects } \\
\text { investigated }\end{array}$ \\
\hline \multirow{2}{*}{$\begin{array}{l}\text { Extent of completion of } \\
\text { diagnosis }\end{array}$} & $\begin{array}{l}\text { Investigated TB suspects with } \geq 1 \\
\text { sputum microscopy }\end{array}$ & $\begin{array}{l}\text { Proportion of first sputum microscopy } \\
\text { examinations in TB suspects }\end{array}$ & $\begin{array}{l}\text { First sputum microscopy examinations / } \\
\text { total TB suspects }\end{array}$ \\
\hline & $\begin{array}{l}\text { Investigated TB suspects with } \geq 1 \\
\text { sputum microscopy and } \geq 1 \text { culture, } \\
\text { both usable for diagnosis }\end{array}$ & $\begin{array}{l}\text { Proportion of TB suspects with final } \\
\text { results usable for diagnosis }\end{array}$ & $\begin{array}{l}\text { TB suspects with sputum microscopy } \\
\text { examinations and culture with usable } \\
\text { results / total TB suspects }\end{array}$ \\
\hline $\begin{array}{l}\text { Public awareness of TB, } \\
\text { its diagnosis and } \\
\text { curability }\end{array}$ & Delay in seeking health care & $\begin{array}{l}\text { Mean time (in days) between symptom } \\
\text { onset and first seeking medical attention }\end{array}$ & $\begin{array}{l}\text { Arithmetic average of delay (days) in } \\
\text { seeking medical attention for all cases }\end{array}$ \\
\hline $\begin{array}{l}\text { Quality of preventive } \\
\text { services }\end{array}$ & $\begin{array}{l}\text { Delay in initiation of epidemiologi- } \\
\text { cal case investigation and contact } \\
\text { tracing }\end{array}$ & $\begin{array}{l}\text { Mean time (in days) between diagnosis } \\
\text { and start of contact tracing }\end{array}$ & $\begin{array}{l}\text { Arithmetic average of delay (days) } \\
\text { between diagnosis of index case and } \\
\text { start of contact tracing }\end{array}$ \\
\hline $\begin{array}{l}\text { Overall quality of } \\
\text { diagnostic services }\end{array}$ & Diagnostic delay & $\begin{array}{l}\text { Mean time (in days) between symptom } \\
\text { onset and diagnosis (different standards } \\
\text { for } A F B+v^{d} \text { TB and AFB-ve TB cases }{ }^{e} \text { ) }\end{array}$ & $\begin{array}{l}\text { Arithmetic average of delay (days) to } \\
\text { diagnosis for all cases }^{c}\end{array}$ \\
\hline \multirow{2}{*}{$\begin{array}{l}\text { Quality of outbreak } \\
\text { control }\end{array}$} & Delay in start of contact tracing & $\begin{array}{l}\text { Mean time (in days) between notification } \\
\text { of index case and start date of contact } \\
\text { tracing }\end{array}$ & $\begin{array}{l}\text { Arithmetic average of delay (days) in all } \\
\text { contacts (in an outbreak, or cumulative) } \\
\text { for all cases }^{c}\end{array}$ \\
\hline & $\begin{array}{l}\text { Contacts with completed initial } \\
\text { investigations }\end{array}$ & $\begin{array}{l}\text { Proportion of reported contacts with } \\
\text { completed initial investigations }\end{array}$ & $\begin{array}{l}\text { Contacts with completed initial studies / } \\
\text { total recorded contacts }\end{array}$ \\
\hline \multicolumn{4}{|c|}{$\begin{array}{l}\text { a TB suspects: respiratory symptoms (cough and/or expectoration) lasting } \geq 2 \text { weeks } \\
\text { b Vulnerable groups: contacts of TB patients; persons with debilitating chronic diseases (such as diabetes, chronic renal insufficiency, HIVI } \\
\text { AIDS, malignancies, chronic obstructive pulmonary disease, any type of immunodeficiency, severe psychiatric illnesses); socioenvironmental } \\
\text { problems (e.g., homelessness); institutionalized populations (e.g. in prisons and psychiatric institutions); persons from highly endemic } \\
\text { countries } \\
\text { c may be calculated for outbreak or cumulatively for a given locality in specific time } \\
\text { d AFB+ve: acid-fast bacilli found on sputum microscopy } \\
\text { e AFB-ve: culture positive for } M \text {. tuberculosis with negative sputum microscopy or patient with clinical and radiological evidence of pulmonary TB } \\
\text { without bacteriological confirmation }\end{array}$} \\
\hline
\end{tabular}

A thoughtful examination reveals, on the one hand, the need to redesign some strategies to make them more efficient, with new processes to achieve desired results (e.g., prioritization of vulnerable groups); and on the other hand, the need for indicators that comprehensively reflect the interactive quality of these different processes-specific to the Cuban context but potentially applicable, all or in part, to others.

It is not possible, for example, to precisely assess the subprocesses for investigation of TB suspects, defined as persons with persistent cough for at least two weeks, without taking into account to what extent the case yield is appropriate. In turn, this is aligned with issues of timely identification and investigation.

For many years we have assessed the achievement of complete TB case diagnosis using as indicators the proportions of first and second sputum samples and cultures performed, which does not indicate whether or not bacteriological investigation has been completed for each patient. This underscores the serious need for qualitative improvement in how we analyze completeness of the diagnostic process.

Can case detection be considered good without taking into account time elapsed between symptom onset and first doctor's visit or between provisional and confirmatory diagnosis?
Currently, indicators of such delays in identified TB cases are not duly analyzed in municipal and provincial PNCT reports because they are not among the indicators selected for cumulative monthly monitoring by the statistical records system. The same could apply to delays in case-finding and completion of investigations required by PNCT for each recorded contact of diagnosed TB cases. Hence, we believe it advisable to move ahead with conceptualization and reformulation of some of these processes, contributing new elements to indicators whose implementation better expresses what needs to be monitored and evaluated.

If case-finding of TB suspects is supposed to be essentially targeted to vulnerable groups, then we need to know if this is really being done and to what extent. If we want to diagnosis $M$. tuberculosis and more accurately evaluate its drug resistance, we need to perform more cultures and monitor how often a culture is done for the first sputum microscopy, something that is not currently emphasized.

There is also a potential need to include effective composite indicators. Geographical areas can be better rated and stratified by adding indicators that distinguish particular aspects, such as identification of TB suspects differentiated by delay in diagnosis and contact followup, and differences between services where per- 
Table 2: Operational indicators for TB case detection with critical observations, Cuba, 1999-2010

Indicator
1. Proportion of TB suspects detected
in outpatient consultation
2. Proportion of first samples per-
formed
3. Proportion of second samples
performed
4. Proportion of cultures performed on
first samples

\section{Proportion of epidemiological} histories taken

6. Proportion of contacts investigated

\section{Proportion of contacts of $A F B+v e$ pulmonary TB cases receiving che- moprophylaxis}

\section{Critical Observation}

Does not qualitatively define or specify scope of screening.

Unit of analysis refers to samples, not to persons.

Unit of analysis refers to samples, not to persons.

What is important is the

proportion of TB suspects with complete and optimal-quality bacteriological investigations.

What is important is history quality.

What is important is whether their initial investigations are completed.

It would be more useful to specify the proportion that completes chemoprophylaxis.

8. Delay between

8.1 First symptoms and first consult as $\mathrm{RS}+14$

8.2 First consult as RS+14 and confirmed diagnosis

8.3 First symptoms and confirmed diagnosis

8.4 Diagnosis and initiation of treatment

8.5 Duration of contact tracing

9. Laboratory results:

9.1 Proportion of positive sputum microscopies

9.2 Proportion of positive cultures

9.3 Proportion of contaminated

cultures

8.1-8.4: data validity must be ensured

8.5: dependent on outbreak characteristics

9.1-9.2: dependent on technical personnel competence and TB prevalence in geographical area

9.3: important for monitoring laboratory quality

AFB+ve: acid-fast bacilli found on sputum microscopy

$\mathrm{RS}+14$ : respiratory symptoms (cough and/or expectoration) lasting $\geq 14$ days (TB suspect)

sonnel are more competent and diligent compared with others where they are less so. This is the reasoning that informs our proposal for several of these new indicators.

We should bear in mind that an indicator is a numerical expression of a fact or event, a specific measure of a program action that is tracked by a monitoring and evaluation system.[1,2] A good indicator should be valid, reliable, specific, sensitive, operational, affordable, feasible and understandable.[2,6] PNCT has been using a set of indicators [7] (of processes, effect or outcome, and impact) that fulfilled their role in the past but do not entirely meet the needs and standards required for today's program.

\section{DISCUSSION}

Revised indicators and new applications The underlying idea is to improve the ability of some indicators to qualitatively and quantitatively express the intent of their specific objective and its corresponding dimension. As explained, PNCT focuses on early identification of TB suspects; it would therefore be of interest to know to what extent this actually occurs.
It is important to have an indicator showing the proportion of TB suspects detected who belong to one of the vulnerable groups identified by PNCT. Case-finding of TB suspects in vulnerable groups has been introduced as an activity in two projects: Assessment of a Set of Differential Tuberculosis Control Interventions[11] and Strengthening the Tuberculosis Control Program in the Republic of Cuba (Global Fund Round 7).[12] Arnol reported that in the health area of the Antonio Guiteras Polyclinic in Old Havana municipality, $81 \%$ of TB suspects were members of vulnerable groups,[13] while Reyes found about $70 \%$ were in vulnerable groups in communities in San Antonio del Sur and Imías municipalities in Guantánamo Province.[14] Both studies were able to obtain the pertinent data from the laboratory register of TB suspects investigated and from interviews with patients, through rapid operational evaluative research.

In the abovementioned projects, variables for constructing this indicator were obtained from tailor-made forms, which have been proposed for inclusion in the PNCT system. This revised indicator for TB suspects is very important at the local level (health area and municipality) for cumulative monthly analysis; the provincial level would require the data quarterly; and the national level could receive it at year-end.

As posited earlier, it would be more useful and effective to determine the percentage of TB suspects identified who fully complete a totally interpretable bacteriological investigation, (sputum microscopy and culture); with complete and perfectly documented results. Statistics about cultures not performed or contaminated are necessary to monitor laboratory performance but are neither useful nor interpretable for diagnosis. In both cases (detection in vulnerable groups and completeness of bacteriological investigation) we need to revamp the indicators to make them more accurate and useful for assessment of program objectives. These indicators can be obtained from documentation routinely kept by the PNCT but if they were not included in the national health system's continuously recorded statistics, they can be obtained through the abovementioned rapid operational evaluative research for the periods considered relevant.

Another indicator, which is even simpler, establishes the regional rate of new TB cases notified in persons aged $\leq 24$ years; TB prevalence in this age group is very low in Cuba and an extremely high proportion thereof would strongly suggest recent exogenous TB exposure[15] and throw light on progress in TB control and elimination.

Furthermore, the health service's performance in completing all relevant contact investigations for diagnosed and notified TB cases is important in prevention and containment of transmission of secondary cases responsible for local TB outbreaks. It is not enough simply to identify contacts during contact tracing; this is effective only when all necessary investigations are completed for each one. Thus the appropriate revamped indicator would be the proportion of contacts with completed initial investigations as established by PNCT.[10]

Other important indicators include:

- Proportion of treatment failures, obtained from identification of positive sputum microscopy examinations in patients under treatment following completion of the fourth month of treatment and verification of sample positivity by culture. This is essential to study acquired resistance to anti-tuberculosis drugs. 
- Proportion of TB deaths for which complete case reports (epidemiological investigation forms) are available and have been discussed in the Provincial TB Committee.

Introduction of new composite and local indicators The current PNCT[10] does not include composite indicators that could complement or refine existing ones. Moving forward, we could apply some indicators that are composites of other, intermediate indicators.[15-19] These are novel, not only in conception, which goes beyond what is described in PNCT and in other guidelines from international agencies,[1,2] but also because they involve variables that provide greater qualitative perspective on TB control. We have developed and proposed three so far, two of which have already been validated for content, face and predictive validity and for feasibility of application.[20] These indicators are the Composite Case-Finding Indicator and the Composite Case Detection Indicator (ISILOC and ISIDEC, the respective Spanish acronyms). Their methods and evaluation have been described elsewhere.[16-19]

As is logical and consistent, there is a need for indicators useful at the municipal level and also within municipalities. Differences among and within areas must be assessed before and during indicator validation and implementation to determine their consistency and discriminative capacity, as was done for the proposed new composite indicators.[17]

\section{FINAL CONSIDERATIONS}

The fact that reliable data from intermediate indicators are needed to calculate ISILOC and ISIDEC requires improving the competency of health service personnel, as is spelled out in the Regional TB Plan guidelines[9] and in the Cuban Ministry of Public Health's objectives in the public health and epidemiology areas.[21] These intermediate indicators offer important value added by fostering better monitoring of indicators and more accurate oversight and application of rapid operational research. It is difficult to rate case detection quality when trying to separately appraise five or more indicators related to its performance. The composite indicators proposed for PNCT facilitate that appraisal using a standardized objective approach. The results of initial[15-19] and more recent tests (technical reports on application of composite indicators, Pedro Kourí Tropical Medicine Institute, 2012) have been satisfactory and provide additional instruments for evaluating these indicators' qualitative reach. Both indicators permit differential classification of geographical areas, from unacceptable to excellent, supporting appropriate decisionmaking for corrective action.

In summary, the principal advantage of the redesigned indicators and new composite indicators is that they would round out and improve criteria for and appraisal of quality of TB case detection, which could contribute to decisionmaking on corrective actions to resolve any shortcomings observed in PNCT implementation going forward.

\section{ACKNOWLEDGMENTS}

This article is part of work to validate composite indicators for tuberculosis surveillance and control, supported by the Global Fund Round 7 TB project. -1 .

\section{REFERENCES}

1. Un marco ampliado de DOTS para el control eficaz de la Tuberculosis. Alianza Alto a la Tuberculosis. Enfermedades transmisibles. Geneva: World Health Organization; 2002. Spanish.

2. Compendium of indicators for monitoring and evaluating National Tuberculosis Programs. Geneva: World Health Organization; 2009.

3. González E, Armas L. Vigilancia y control de la tuberculosis. Experiencia cubana. Havana: Institute of Tropical Medicine (CU); 2010. Spanish.

4. Marrero A, Caminero JA, Rodríguez R, Billo NE. Towards elimination of tuberculosis in a lowincome country: the experience of Cuba 196297. Thorax. 2000 Jan;55(1):39-45.

5. González E, Armas L, Baly A, Gálvez A, Álvarez $M$, Ferrer $G$, et al. Impacto económico-social del programa de control de tuberculosis en la población cubana. Cad Saude Pública Río de Janeiro. 2000;16(3):687-99. Spanish.

6. González E, Armas L, Llanes MJ. Progress towards tuberculosis elimination in Cuba. Int $\mathrm{J}$ Tuberc Lung Dis. 2007 Apr;11(4):405-11.

7. González E, Risco G, Borroto S, Perna A, Armas L. Tuberculosis mortality trends in Cuba 19982007. MEDICC Rev. 2009 Winter;11(1):42-7.

8. Borroto S, González E. Notificación de la tuberculosis en Cuba 2008-2010. Bol IPK [Internet]. 2011 [cited 2011 Apr 12]; 21:65-71. Available from: http://files.sld.cu/ipk/files/2011/04/bol09 -11.pdf. Spanish.

9. Pan American Health Organization. Regional Plan for Tuberculosis Control, 2006-2015. Washington, DC: Pan American Health Organization; 2006.

10. Ministry of Public Health (CU). Programa Nacional de Control de la Tuberculosis en Cuba [Internet]. Havana: ECIMED; 2010 [cited 2011 Apr 12]. Available from: http://www.sld.cu/galerias/pdf/ sitios/tuberculosis/manual.pdf. Spanish.
11. Valoración de intervenciones diferenciadas para el control y eliminación de la tuberculosis. Proyecto de investigación Ramal (apoyado por el instituto de cooperación Belga mediante el Instituto de Medicina Tropical de Amberes). Havana: Institute of Tropical Medicine (CU); 2006. Spanish.

12. Fortalecimiento del programa de control de la tuberculosis en la República de Cuba. Proyecto apoyado por el Fondo Mundial para el Sida, la malaria y la tuberculosis en su Ronda 7 , mediante el PNUD [Internet]. Havana: Ministry of Public Health (CU); 2008. Available from: http://www .undp.org.cu/proyectos/tuberc.html. Spanish.

13. Arnol Y. Selección de Sintomáticos respiratorios según riesgo de padecer tuberculosis pulmonar. Sept 2004-Sept 2005 [thesis]. [Havana]: Calixto García Medical School; 2007. Spanish.

14. Reyes G. Selección de sintomáticos respiratorios según riesgo de padecer tuberculosis en dos policlínicos de la provincia Guantánamo. Jul 2006-Jun 2007 [thesis]. [Havana]: Institute of Tropical Medicine; 2008. Spanish.

15. González E, Armas L. Propuesta de un indicador sintético de la infección tuberculosa exógena reciente (INSIERT). Bol IPK 2011;2:09-11. Spanish.

16. Armas L, Medina NL, Peralta M, González E. Un indicador sintético (ISILOC) para valorar la calidad de la detección de casos de tuberculosis. Rev Cubana Med Trop [Internet]. 2009 [cited 2012 Apr 21];61(1):63-9. Available from: http://scielo.sld.cu/scielo.php?script=sci _pdf\&pid=S0375-07602009000100009\&Ing=es \&nrm=iso\&tlng=es. Spanish.

17. Gómez P, Méndez J, Armas L, González E. Evaluación de la detección de casos de tuberculosis mediante un indicador sintético (ISILOC). Provincia Matanzas. Rev Med Electrón [Internet]. 2009 [cited 2012 Mar 07];31(4). Available from: http://scielo.sld .cu/pdf/rme/v31n4/spu05409.pdf. Spanish.
18. Jordán $T$, Oramas $R$, Díaz $O$, González E, Armas L. Evaluación de la detección de casos de tuberculosis mediante un indicador sintético en dos municipios de Ciudad de la Habana. Rev Cubana Hig Epidemiol [Internet]. 2008 [cited 2012 Mar 07];46(3):1-9. Available from: http://redalyc.uaemex.mx/src/inicio/ArtPdfRed .jsp?iCve=223217511004. Spanish.

19. González E, Jordán T, Armas L. Aplicación de un indicador sintético de la detección de casos de tuberculosis (ISIDEC). Bol IPK [Internet]. 2011 [cited 2011 May 15];21:105-7. Available from: http:// files.sld.cu/ipk/files/2011/06/bol14-11.pdf. Spanish.

20. Silva LC. Cultura estadística e investigación en salud: una mirada crítica. Madrid: Díaz de Santos SA; 1997. Spanish.

21. Objetivos de trabajo y lineamientos para el año 2012. Área de Higiene y Epidemiología. Havana: Ministry of Public Health (CU); 2012. Spanish.

\section{THE AUTHORS}

Edilberto R. González Ochoa (Corresponding author: ochoa@ipk.sld.cu), physician epidemiologist with a doctórate in health sciences. Full professor and senior researcher, Pedro Kourí Tropical Medicine Institute (IPK), Havana, Cuba.

Luisa Armas Pérez, pulmonologist. Associate researcher and associate professor, IPK, Havana, Cuba.

Submitted: April 29, 2012

Approved for publication: October 14, 2012 Disclosures: None 